the staff of the Ministry, but it is obvious that the hands of the Ministry must be left free. In certain and very special cases it may be necessary to utilise the experience of the Board of Control, and the Minister should be left free to do so."

Unfortunately the treatment of mental disorder is a branch of medicine which more than any other is hampered by the exigencies of the law, and this has made our advancement slow. The system in the past has been too narrow and the remedy for the removal of the "stigma of lunacy" by treating voluntary and detained patients in county and borough asylums, as suggested by the writer of this note, is far from being a hopeful one when we bear in mind that registered mental hospitals and licensed houses have for thirty years been able to do this. No, the remedy lies in a far wider vision, and unless we, as an Association, can show by our policy that we have this, there is little doubt that we shall, and rightly, be superseded by those who have.

87, Harley Street, W. I ;

I am, Sirs, your obedient servant, March 16 th, 1921.

[Sir Maurice Craig is correct in his supposition that our Editorial remarks on Clause to of the Ministry of Health (Miscellaneous Provisions) Bill are not an official expression of opinion of the Medico-Psychological Association. He need be under no misapprehension regarding the writer he refers to. "Occasional Notes" are Editorial utterances for which the Editors are solely responsible. Neither is any such claim as he mentions made. The Association sent a wire to the Minister of Health definitely stating that it desired the clause to be withdrawn if its amendments were not accepted. The amendments not being found acceptable, it is obvious that the comment in the early part of paragraph I was fully justified. The attitude taken up by the Ministry on this subject as regards the mental hospitals and Board of Control is too well known to the Association to need recapitulating here. The Association will be glad to learn that as far as Sir Maurice Craig is concerned he is one with us that "any concession as to early treatment should be enjoyed by all mental hospitals, etc." Such an assurance would have been better timed when the Bill was under consideration by the Association, but it is nevertheless welcome. We venture to think that this is just the soul and centre of the Association claim, neither more nor less. We do not propose to discuss the remaining points of the letter. Members will judge for themselves as to the correctness or propriety of the Journal's remarks on this subject. We will only say that any measure under which there is the chance of excluding the great majority of practising alienists from the treatment of incipient, recent or acute cases, whether certified or not, is of doubtful efficiency, and will react unfavourably on the status of the established mental hospitals and their patients.-EDs.]

\title{
OBITUARY.
}

\section{Antoine RitTi.}

IT was a very little company that on January 25 th, 1920, followed to its last resting-place the body of Antoine Ritti, borne, in compliance with his request, upon the pauper's bier. His wishes that no letters of invitation should be sent out and no oration delivered were scrupulously observed, and not till afterwards did a laconic announcement he had himself drawn up appear in an evening paper. It was all very simple and business-like, characteristic of the man and everything he did. So passes from the ranks of medicine a good and faithful servant and from the roll of honorary members of our Association a distinguished name.

Born in 1844 , under the shadow of the cathedral of Strasbourg, where his uncle was bishop, and educated at the Catholic Gymnase at Colmar, founded by that same uncle, he was considered by his relatives to have a vocation for the church but when he was about twenty years old he embraced the positive philosophy of Auguste Comte, and a little later became a student of medicine. Clouds hung over his student days; he was interne at an obscure provincial asylum under fameless chiefs (Fains, 1867-70), his studies were interrupted by the FrancoPrussian war, and he was uprooted from his native Alsace by his choice of French nationality. He entered upon the practice of his profession in 1874 as a medical 
officer of the Bureau de Bienfaisance in the VIe Arrondissement of Paris. How, under such auspices, he early attracted the notice of men like Baillarger and Jules Falret is not now clear; but in 1875 he became an assiduous contributor to the Anrales Médico-psychologiques, of which Baillarger and Lunier were then the editors. Dr. Georges Vernet, from whose delightful sketch in the Annales the materials for this record are drawn, tells us that those were still the happy times when young men, reading much, wrote little, and only when they knew how to hold a pen; yet sometimes an article that made a good impression would stamp an author and decide a selection, and probably it was so in Ritti's case.

In 1878 a crisis occurred in the history of the Maison Nationale, Charenton, This famous institution, from which the discovery of general paralysis had been announced to the world, was in evil plight; the posts formerly occupied there by Esquirol and Bayle, by the Fovilles and the venerable Calmeil, had of late, through jobbery and influence, been given to persons who were utter strangers to mental medicine. An end had to be put to this state of things. A concours sur titres was held, with a jury that included several distinguished alienists; and at an election that cannot have been easy, for Bourneville, Doutrevente and Jules Voisin were among the candidates, Christian and Ritti were appointed physicians-Christian for the male side and Ritti for the female. On February 15th, 1879, they entered upon their duties simultaneously. They had a difficult task before them, to restore the prestige and moral authority of the medical staff and to recall to the Maison Nationale the attention of the scientific world. These two men, of widely different types of mind, realised the need for unanimity and concerted action; they sealed a pact which for twenty-six years was by both of them religiously maintained.

The last twenty years of the nineteenth century were marked by important discussions in mental medicine, and the debates in learned societies were often very animated. It was a matter of course that in these debates Charenton must be represented. Christian was its mouthpiece; he had great powers as a speaker. But he owed to Ritti, less gifted in this respect, and always ready to efface himself before his older colleague, great stores of valuable data, much fruit of erudition, and many of the happy phrases that characterised his interventions. His scientific work he mostly handed over to Ritti for publication. Ritti himself wrote many papers. Besides his Traité clinique de la folie à double forme (folie circulaire delire a formes alternes), to which the Academy of Medicine awarded the Falret prize in 1880 , there were papers on the relations between general paralysis and syphilis (1879, 1888), many articles in Dechambre's Dictionary, and much else. He remained at Charenton for over thirty years. The last months were saddened by incidents he could never afterwards recall without bitterness. Feeling one day that he had not been treated with the respect due to him, he resigned. Prematurely, in full intellectual and physical vigour, he left the Maison Nationale in October, 1909.

Ritti's share in the advancement of our science was not that of a discoverer or explorer; his task, no less important, was to convert into smooth road the rough path that others had found. Much valuable work of this kind he accomplished not only by the writings that have been referred to, but in other ways that have now to be mentioned. In 188I he was elected general secretary of the Société Médico-psychologique, and he was re-elected annually until his death. President after president, in speaking of the services he thus rendered, exhausted the vocabulary of laudatory epithets; the least that they said of him was that he was the soul of the Société. But to him it never seemed strange that his qualities of regularity, punctuality, and precision should be at its service. He wrote the reports of over five hundred of its meetings, including abstracts of innumerable papers and speeches. In 1885, when Lunier died, he was chosen to be one of the editors of the Annales Médico-psychologiques, and in 1890, on the death of Baillarger, he became principal editor, and he remained so for the rest of his life. In the ways in which he exercised both his secretarial and editorial functions he was somewhat old-fashioned. He had a great respect for tradition. His editing was no indiscriminate acceptance of whatever manuscript came to him; he used the blue pencil freely. And in the Sociéte he regularly observed the old-established and decent custom by which, at each April meeting, the secretary would read a biographical notice of any member deceased in the preceding year. These eloges, and others that he delivered at the unveiling of the statue of Pinel, the busts of 
Baillarger and J. P. Falret, and the busts of Pinel and Esquirol at Toulouse, are written in impeccable French and breathe a severely classic spirit.

He was the recipient of many marks of distinction, including the Legion of Honour, the presidency of the Congress of French-speaking Alienists and Neurologists, the presidency of the Clinical Society of Mental Medicine, and the presidency of the Mutual Association of French Alienists.

He died, after a brief illness, at the villa at Auteuil, to which, on leaving the Maison Nationale, he had retired, where neither Gothas nor Berthas had ever succeeded in driving him from among his books. He bequeathed 20,000 francs to the Mutual Association of French Alienists, and the residue of his fortune to the Academy of Medicine and other learned bodies for the founding of prizes in mental medicine.

Peculiarly appropriate to Ritti himself are the noble words in his eloge of Calmeil : "Ennemi du faste et du bruit, Calmeil nous lègue à tous l'exemple de ce que peuvent, pour le progrès des connaissances et même pour le bonheur individuel, le gout de la retraite, la passion du savoir et l'amour de la vérité. Puisse ce modêle si achevé du médecin aliéniste modeste, consciencieux, esclave du devoir, trouver de nombreux imitateurs, au grand profit de la science et de l'humanité."

David Yellowlers, M.D.Edin., LL.D.Glasg.

THE recent decease, full of years and honours, of Dr. David Yellowlees removes from our midst one of the few remaining pioneers of the renaissance which occurred in British psychiatry during the later decades of. the nineteenth century.

Reference was made to his personality and career by the President, Dr. W. F. Menzies, at the Quarterly Meeting of the Association in February, and also by Dr. R. B. Campbell at the March meeting of the Scottish Division. We hope to publish an extended biography in a future number of the Journal.

The Lancet in its obituary notice (February 5th, 1921) says :

"With the death of Dr. Yellowlees at Edinburgh, on January 19th, in his eighty-fifth year, has passed away a man who combined high professional attain. ment in mental medicine with a gift for administration. David Yellowlees was born and brought up at Stirling, graduated at Edinburgh in 1857, and after a period of study abroad returned as assistant to Sir William Gairdner at the Edinburgh Royal Infirmary. His first appointment in psychiatry was to assist Dr. Skae at the Edinburgh Royal Asylum, Morningside, and in 1863 he went to direct the Glamorgan County Asylum, where he remained twelve years. In 1874 he followed Dr. Mackintosh as Physician-Superintendent to the Royal Glasgow Asylum, Gartnavel, a post which failing eyesight obliged him to relinquish in $190 \mathrm{r}$. During the greater part of this tinie he lectured on insanity in the University of Glasgow, which conferred upon him the honorary degree of LL.D. in 1888. He presided over the Psychological Section of the British Medical Association which met at Glasgow in 1885, over the Medical-Psychological Association in 1890, and over the Faculty of Physicians and Surgeons of Glasgow in 1892-94.

"Under Yellowlees Gartnavel became a keen centre of psychiatric thought. His physical energy and enthusiasm, combined with a radiant optimism, infected his assistants, as well as in some measure the patients and their friends. His routine was to entrust each of his helpers with the entire responsibility of a part of the asylum, and to hear and discuss their reports at his own house every day at noon. He then visited the wards independently, acting as a kindly and sagacious consultant. Simple and frank himself, he expected, and generally found, the same qualities in others, who grew to rely upon his honest and fearless character.

"Dr. Yellowlees took a leading part in the philanthropic work of the city which became his second home. He was for the greater part of his active life on the directing board of the Association for the Relief of Incurables, the Brambill Home for Incurables, and the Lanfine Home for Consumptives. He helped to found the Glasgow Association for the Care of Defective and Feeble-minded Children, and 